\title{
PERAN KEPEMIMPINAN KEPALA SEKOLAH DALAM MENANGANI SISWA DENGAN PERILAKU BERMASALAH DI MTS AL-HIKMAH MOGUTAT KOTAMOBAGU
}

\author{
Haslinda Mokodompit \\ IAIM KOTAMOBAGU \\ Jl. Jhoni Suhodo, Kotabangon, Kotamobagu Tim., Kota Kotamobagu, \\ e-mail : iksanmokompit2020@gmail.com
}

\begin{abstract}
Abstrak : Tujuan penelitian: 1) Untuk menganalisis penanganan terhadap siswa bermasalah pada MTs Al-Hikmah Mogutat Kotamobagu; 2) Untuk menganalisis peran kepemimpinan dalam menangani perilaku siswa bermasalah pada MTs AlHikmah Mogutat Kotamobagu. Metodologi penelitian yaitu: pendekatan kualitatif, dengan informan kepala dan wakil kepala madrasah, guru, dan siswa di MTs Al-Hikmah Mogutat Kotamobagu. Teknik pengumpulan data menggunakan observasi, wawancara, dan dokumentasi. Hasil penelitian: 1) Penanganan siswa yang berperilaku menyimpang di MTs Al-Hikmah Mogutat Kotamobagu ada beberapa cara yaitu: melakukan bimbingan terhadap siswa, melibatkan orang tua, guru, kepala madrasah dalam penanganan anak berperilaku menyimpang. 2) Peran kepemimpinan dalam menangani gangguan perilaku siswa di MTs Al-Hikmah Mogutat Kotamobagu sangat berperan, di mana kepala madrasah selalu menginstruksikan kepada guru untuk memberikan laporan perkembangan anak termasuk aspek sikap, melakukan identifikasi terhadap permasalahan siswa, dan menciptakan solusi yang efektif dalam menangani permasalahan siswa. Kepala madrasah selalu melibatkan baik itu unsur guru dan orang tua dalam menangani permasalahan siswa di MTs Al-Hikmah Mogutat Kotamobagu.
\end{abstract}

\begin{abstract}
Research objectives: 1) to analyze handling of a troubled student in MTs Al-Hikmah Mogutat Kotamobagu; 2) to analyze the role of leadership that we are doing in dealing with the behavior of a troubled studen In MTs Al-Hikmah Mogutat Kotamobagu. Research methodology: a qualitative approach, with informants head and deputy head of madrasah, teachers, and students in MTs AlHikmah Mogutat Kotamobagu. Technique data collection use observation, interview, and documentation. The research: 1) handling of students who behaves swerved in MTs Al-Hikmah Mogutat Kotamobagu there are several ways either: conducting guidance for students, involving parents, teachers, head of Islamic school in handling children to behave. 2) leadership in dealing with bullying behavior students in MTs Al-Hikmah Mogutat Kotamobagu play an important role, in which the head madrasah always for teachers to instruct the including aspects of a child development, students carried out the identification of the problems, and create an effective in dealing with the students.
\end{abstract}

Kata Kunci: Kepemimpinan, Kepala Sekolah, Gangguan Perilaku, Siswa 
Journal of Islamic Education Policy Vol. 4 No. 2 Juli - Desember 2019

\section{Pendahuluan}

Dalam mengelola madrasah tentunya seorang pemimpin mendapatkan berbagai masalah, terutama menghadapi para siswa yang bermasalah di madrasah atau sekolah. perilaku bermasalah siswa mempunyai banyak jenis, mulai dari masalah yang ringan (data terlambat ke madrasah), masalah yang sedang (merokok dan bolos), maupun masalah yang berat (berkelahi dan narkoba). Hal ini seringkali terjadi di madrasah-madrasah di Indonesia, untuk perlu adanya kegiatan-kegiatan yang efektif untuk meminimalisir permasalahan-permasalahan tersebut. Seorang siswa yang dikategorikan sebagai anak yang bermasalah apabila ia menunjukkan gejala-gejala penyimpangan dari perilaku yang lazim di lakukan oleh anak-anak pada umumnya. ${ }^{1}$ Perilaku menyimpang adalah suatu persoalan yang harus menjadi kepedulian guru, bukan semata-mata perilaku itu destruktif atau mengganggu proses pembelajaran, melainkan suatu bentuk perilaku agresif atau pasif yang dapat menimbulkan kesulitan dalam bekerja sama dengan teman, yang merupakan perilaku yang dapat menimbulkan masalah belajar anak dan hal itu termasuk perilaku bermasalah. ${ }^{2}$

Untuk mengatasi permasalahan tersebut dibutuhkan kemampuan manajerial seorang pemimpin, yang intinya dapat membuat keputusan-keputusan yang tepat untuk penanganan perilaku siswa bermasalah. Dalam kepemimpinan manajerial setidaknya seorang pemimpin harus mempunyai 3 (tiga) keterampilan, yaitu: keterampilan konseptual (conceptual skills), keterampilan hubungan manusia (human skills), dan keterampilan teknikal (technical skills). ${ }^{3}$ Selanjutnya perlu dibuat kebijakan-kebijakan yang tepat guna melakukan penanganan terhadap para siswa yang bermasalah di madrasah. Kebijakan adalah keputusan suatu organisasi yang dimaksudkan untuk mengatasi permasalahan tertentu sebagai keputusan atau untuk mencapai tujuan tertentu, berisikan ketentuan-ketentuan yang dapat dijadikan pedoman perilaku dalam (1) pengambilan keputusan lebih lanjut, yang harus dilakukan baik kelompok sasaran ataupun (unit) organisasi pelaksana kebijakan, (2) penerapan atau pelaksanaan dari suatu kebijakan yang telah ditetapkan baik dalam hubungan dengan (unit) organisasi pelaksana maupun dengan kelompok sasaran yang dimaksudkan. ${ }^{4}$

Dari uraian di atas menunjukkan pentingnya interaksi antara guru dengan siswa. Guru bertugas untuk memberikan pendidikan, pengajaran, dan pelatihan. Untuk penanganan siswa bermasalah dibutuhkan interaksi yang baik antara guru dengan siswa. Guru selalu memberikan pembinaan, sedangkan siswa harus mengikuti seluruh arahan-arahan untuk dilaksanakan sehingga dapat membentuk kepribadian siswa itu sendiri.

Dalam pembelajaran di dalam kelas, proses komunikasi akan berlangsung baik antara guru ke siswa dalam hal ini, peserta didik atau sebaliknya antara peserta didik dengan guru atau pendidik di mana materi pembelajaran merupakan pesan dalam proses komunikas pembelajaran yang sering dipandang sebagai jantung atau inti kegiatan pembelajaran. Dalam komunikasi pembelajaran inilah terjadi Intraksi edukatif yang berlangsung dalam bentuk pertukaran pesan yang tidak lain adalah materi pembelajaran. Dalam konteks komunikasi pembelajaran Guru ditempatkan dalam posisi sebagai komunikator oleh karena tugas dan peran guru sebagai pemimpin pembelajaran memposisikan menjadi komunikator sedangkan

\footnotetext{
${ }^{1}$ Dalyono, Psikologi Pendidikan (Jakarta: Rineka Cipta, 2009), h. 260

2 Abu Darwis, Pengubahan Perilaku Menyimpang Murid SD (Jakarta: Departemen Pendidikan Nasional Direktorat jendral Pendidikan Tinggi Direktorat Ketenagaan, 2006), h.43

${ }^{3}$ Wahyudi, Kepemimpinan Kepala Sekolah dalam Organisasi Pembelajar (Bandung: Alfabeta, 2012), h.68

${ }^{4}$ Mustopadidjaja, Kebijakan Efektif dan Efisien (Jakarta: LAN RI Jakarta, 2009), h.12
} 
siswa ditempat sebagai komunikan atau peserta didik. Guru harus mampu menguasai pola interaksi dan teknik komunikasi yang baik dalam proses pembelajaran. Interaksi dalam pembelajaran lebih dikenal dengan istilah interaksi edukatif. Interaksi edukatif secara spesifik merupakan proses atau interaksi belajar mengajar memiliki ciri-ciri khusus yang membedakan dengan bentuk interaksi lain. Ciri-ciri Interaksi Belajar Mengajar tersebut yaitu interaksi belajar-mengajar memiliki tujuan, ada suatu Prosedur (jalannya inetraksi) yang terencana, interaksi belajar mengajar di tandai dengan suatu penggarapan materi yang khusus, ditandai dengan adanya aktivitas siswa, dalam interaksi belajar mengajar guru berperan sebagai pembimbing, di dalam interaksi belajar mengajar membutuhkan disiplin, dan ada batas waktu. ${ }^{5}$

Studi awal sebagaimana catatan lapangan yang dilakukan oleh peneliti di MTs AlHikmah Mogutat Kotamobagu seorang guru kelas VII sering menemukan masalah siswa kurang konsentrasi karena siswa yang lain mengganggu temannya saat pembelajaran, membuat keributan dan lambat menerima pembelajaran. Masih ada siswa yang mengajak temannya keluar kelas ke Kantin pada saat pembelajaran. Pada kegiatan pembelajaran ada beberapa siswa tidak menulis dan mendengarkan penjelasan yang dijelaskan oleh guru, dan ketika guru menegurnya siswa tersebut berpura-pura tidak tahu, ketika guru sedikit lengah, siswa tersebut kembali membuat keributan. Pada saat istirahat beberapa siswa bermain sambil memukul-mukul meja dan berteriak-teriak, sehingga kelas menjadi tidak nyaman. Di samping itu juga pada observasi awal ada siswa yang pasif, lambat menerima pembelajaran dan butuh waktu yang lama untuk menyelesaikan tugas.

Hasil wawancara dengan guru di MTs Al-Hikmah Mogutat Kotamobagu yaitu siswa yang bermasalah karena bolos umumnya kelas VII dan kelas VIII, pernah juga ada yang menghirup eha bond atau komix yang berakibat buruk terhadap kesadaran siswa. Penyelesaiannya yaitu menyurati orang tua, guru rapat bersama, kepala madrasah mengambil kebijakan dengan teguran kepada siswa lewat pembinaan orang tua, kepala madrasah, wali kelas dan kesiswaan. Ada juga saling mengejek nama orang tua yang berujung pada perkelahian antar siswa. Penyelesaiannya membuat surat panggilan orang tua, wali kelas, kepala madrasah, berkomunikasi langsung dengan tua siswa atau siswi yang bersangkutan. ${ }^{6}$ Anak yang bermasalah adalah anak dengan gangguan perilaku sulit berempati, sulit mengidentifikasi perilaku positif dalam hubungan interpersonal dan sosial, sulit berinisiatif melakukan kontak sosial sesuai usia, dan cenderung mengatasi masalah dengan cara berperilaku agresif. ${ }^{7}$

Hal ini menunjukkan masih banyak anak yang bermasalah dalam pembelajarannya, untuk itu pentingnya kepemimpinan kepala madrasah memberdayakan potensi madrasah, sehingga dapat menangani anak-anak yang bermasalah tersebut. Menurut Burhanuddin dalam Heri Gunawan Pendidikan dapat diartikan sebagai suatu kesiapan kemampuan yang dimiliki oleh seseorang dalam proses mempengaruhi, mendorong, membimbing, mengarahkan dan menggerakkan orang lain yang ada hubungannya dengan pelaksanaan dan pengembangan pendidikan dan pengajaran, agar segenap kegiatan pembelajaran dapat

\footnotetext{
${ }^{5}$ Ety Nur Inah, Peran Komunikasi Dalam Interaksi Guru Dan Siswa, Jurnal Al-Ta'Dib Vol. 8 (2) 2015

${ }^{6}$ Wawancara dengan Kusmiran Mandjurangi, guru di MTs Al-Hikmah Kotamobagu tanggal 8 Mei 2018

7 Aini Mahabbat, Pola Perilaku Bermasalah Dan Rancangan Intervensi Pada Anak Tunalaras Tipe Gangguan Perilaku (Conduct Disorder) Berdasarkan Functional Behavior Assessment, Jurnal Dinamika Pendidikan Vol. 01 (21) Tahun 2014, h.3
} 
berjalan secara efektif dan efisien yang pada gilirannya dapat mencapai tujuan pendidikan dan pengajaran yang telah ditetapkan. ${ }^{8}$

Jadi peran dari kepemimpinan kepala madrasah sangatlah penting dalam membuat kebijakan-kebijakan untuk penanganan anak-anak yang bermasalah. MTs Al-Hikmah Mogutat Kotamobagu mempunyai kepala madrasah yang aktif dalam melakukan pengawasan terhadap guru dan siswa. Pengawasan kepala madrasah salah satunya adalah memperhatikan siswa-siswa yang bermasalah. Melalui penelitian ini peneliti akan melihat bagaimana peran kepala madrasah untuk menangani anak-anak yang bermasalah di MTs Al-Hikmah Mogutat Kotamobagu.

Pendekatan kualitatif yang menjadi sasaran kajian atau penelitian adalah kehidupan sosial atau masyarakat sebagai sebuah satuan atau sebuah kesatuan yang menyeluruh. Pendekatan kualitatif biasanya dikaitkan dengan pengertian yang sama dengan pendekatan yang dalam antropologi dikenal dengan nama pendekatan holistik. Dalam pendekatan tersebut tidak dikenal adanya sampel; tetapi penelitian harus dilakukan secara teliti, mendalam dan menyeluruh untuk memperoleh gambaran mengenai prinsip-prinsip umum atau pola-pola yang berlaku umum sehubungan dengan gejala-gejala yang ada dalam kehidupan sosial masyarakat yang diteliti sebagai kasus itu sendiri. ${ }^{9}$ Penelitian kualitatif menunjukkan bahwa pelaksanaan penelitian ini memang terjadi secara alamiah, apa adanya, dalam situasi normal yang tidak dimanipulasi keadaan dan kondisinya, menekankan pada deskripsi secara alami, pengambilan data atau penjaringan fenomena dilakukan dari keadaan yang sewajarnya ini dikenal dengan sebutan " pengambilan data secara alami atau natural". Dengan sifatnya ini maka dituntut keterlibatan peneliti secara langsung di lapangan. ${ }^{10}$ Uraian secara naratif yaitu untuk menguraikan tentang peran kepemimpinan kepala madrasah dalam menangani siswa dengan gangguan perilaku di MTs Al-Hikmah Mogutat Kotamobagu.

\section{Konsep Kepemimpinan Kepala Madrasah}

Kepemimpinan pada dasarnya ialah kemampuan menggerakkan, memberikan motivasi dan mempengaruhi orang-orang agar bersedia melakukan tindakan-tindakan yang terarah pada pencapaian tujuan melalui keberanian mengambil keputusan tentang kegiatan-kegiatan yang harus dilakukan. Kepemimpinan juga merupakan proses interaksi antar kedua belah pihak yaitu seorang pemimpin dan yang dipimpinnya. ${ }^{11}$ Kepemimpinan didefinisikan sebagai seni atau proses untuk mempengaruhi dan mengarahkan orang lain agar mereka mau berusaha mencapai tujuan yang hendak dicapai oleh kelompok. Definisi ini tampak bahwa seorang pemimpin bertugas mendorong bawahannya untuk mencapai tujuan sesuai dengan kemampuan yang ada. jadi seorang pemimpin harus menjadi fasilitator anggota kelompokan dalam mencapai tujuan. ${ }^{12}$ Kepemimpinan pada dasarnya ialah kemampuan menggerakkan, memberikan motivasi dan mempengaruhi orang-orang agar bersedia melakukan tindakantindakan yang terarah pada pencapaian tujuan melalui keberanian mengambil keputusan tentang kegiatan yang harus dilakukan. Kepemimpinan juga merupakan proses interaksi antara kedua belah pihak yaitu seorang pemimpin dan yang dipimpinnya. ${ }^{13}$

\footnotetext{
${ }^{8}$ Heri Gunawan, Pendidikan Karakter "Konsep dan Implementasi” (Bandung: Alfabetha, 2014), h.142

${ }^{9}$ Hamid Patilima, Metode Penelitian Kualitatif (Cet. I; Bandung: Alfabeta, 2005), h.3

${ }^{10}$ Suharsimi Arikunto, Prosedur Penelitian Suatu Pendekatan Praktik (Ed. Revisi, Cet. 14; Jakarta: Rineke Cipta, 2010), h.22

${ }^{11}$ Heri Gunawan. Pendidikan Karakter "Konsep dan Implementasi”, h.141

12 Kadarman dan Jusuf Udaya, Pengantar Ilmu Manajemen (Cet.II; Jakarta: Gramedia Pustaka Utama, 1992), h.116

${ }^{13}$ Heri Gunawan. Pendidikan Karakter "Konsep dan Implementasi” h.142
} 
Kepemimpinan sebagai kemampuan untuk mempengaruhi kelompok menuju pencapaian sasaran. Sumber dari pengaruh ini dapat bersifat formal, seperti yang disajikan kepemilikan peringkat manajerial dalam organisasi. Karena posisi manajemen muncul bersama sejumlah tingkat wewenang yang dirancang secara formal. ${ }^{14}$ Kepemimpinan dapat diartikan sebagai penggunaan pengaruh dimana semua hubungan dapat melibatkan pimpinan. Pentingnya proses komunikasi dimana ada kejelasan dan keakuratan untuk mempengaruhi perilaku dan kinerja pengikutnya. Kepemimpinan memfokuskan pada tujuan yang dicapai, pemimpin yang efektif harus berhubungan dengan tujuan-tujuan individu, kelompok dan organisasi. ${ }^{15}$ Kepemimpinan tidak harus dibatasi oleh aturan-aturan atau tata krama birokrasi. Kepemimpinan tidak harus diikat terjadi dalam suatu organisasi tertentu, melainkan kepemimpinan bisa terjadi dimana saja, asalkan seseorang menunjukkan kemampuannya mempengaruhi perilaku orang-orang lain ke arah tercapainya suatu tujuan tertentu. ${ }^{16}$

Seorang pemimpin seharusnya mengubah gaya kepemimpinannya agar cocok dengan situasi tertentu. Kepribadian seorang pemimpin dalam keadaan darurat umpamanya dapat berbeda banyak sekali dari kepribadiannya ketika kondisi-kondisi kerja normal. Selanjutnya para pemimpin adakalanya menggunakan teknik-teknik kepemimpinan positif dan pada saatsaat lain mungkin menggunakan teknik-teknik kepemimpinan yang negatif. Para pemimpin yang efektif mungkin berpendapat bahwa dalam beberapa situasi suatu bentuk pimpinan yang paling efektif adalah otokratis dan dalam keadaan-keadaan lain bahwa pendekatan partisipatif tau bahkan pendekatan kendali bebas adalah yang berguna. ${ }^{17}$

\section{Perilaku Bermasalah pada Remaja (Juvenile Delinquency)}

Remaja bermasalah atau sering di kenal sebagai anak nakal dalam bahasa Inggris dikenal dengan istilah "Juvenile delinquency" yang mempunyai arti perilaku anak yang melanggar hukum dan apabila dilakukan orang dewasa termasuk kategori kejahatan, termasuk perilaku pelanggaran anak terhadap ketentuan perundang-undangan yang diperuntukkan bagi mereka. ${ }^{18}$ Tekanan-tekanan sebagai akibat perkembangan fisiologis pada masa siswa, ditambah dengan tekanan akibat perubahan kondisi sosial budaya serta perkembangan ilmu pengetahuan dan teknologi yang demikian pesat seringkali mengakibatkan timbulnya masalah-masalah psikologis berupa gangguan penyesuaian diri atau gangguan perilaku. ${ }^{19}$

Anak yang bermasalah atau berperilaku buruk merupakan tanggapan atau reaksi individu yang terwujud dalam gerakan (sikap) dan ucapan yang tidak menyenangkan orang lain. orang tua mana yang tidak marah bila melihat anaknya bertengkar, berbohong, mencuri, marah-marah, malas mengerjakan pekerjaan rumah, tidak mau diatur, mengamuk, mengejek, memukul, berbicara kasar dan tidak sopan membantah, menyelah orang tua sedang berbicara.

${ }^{14}$ Stephen P. Robbins, Perilaku Organisasi (Penerjemah; Benyamin Molan, Jakarta: Indeks Kelompok Gramedia, 2006), h.432

${ }^{15}$ Suwatno dan Priansa, Manajemen SDM dalam Organisasi Publik dan Bisnis (Bandung: Alfabeta, 2016), h. 141

${ }^{16}$ Miftah Thoha, Perilaku Organisasi “Konsep Dasar dan Aplikasinya (Cet. 8; Jakarta: Raja Grafindo, 1996), h.229

${ }^{17}$ Stan Kossen, Aspek Manusiawi dalam Organisasi (Penerjemah; Bakri Siregar; Jakarta: Erlangga, 1993), h.181

18 Sidiq Fatonah, Konsep Penanganan Anak Bermasalah Menurut Alexander Sutherland Neill Dan Implikasinya Terhadap Pendidikan Islam, Jurnal Pendidikan Islam Vol 1 (1) Tahun 2014, hh.1-13

${ }_{19}$ M. Fahli Zatra Hadi, A. Muri Yusuf, Syahniar, Pemahaman Konselor Sekolah Tentang Tugas Perkembangan Siswa Dan Layanan Yang Diberikan, Jurnal Ilmiah Konseling Vol. 2 (1) tahun 2013, hh.43-52 
Mungkin bukan hanya ibu yang marah, melainkan juga teman-teman, tetangga, kakek dan nenek, sehingga orang tua merasa tidak nyaman dan bersalah. ${ }^{20}$

Gangguan perilaku apabila tidak segera di atasi dapat menyebabkan anak berperilaku keras atau kejam serta mengalami problem interpersonal, mental, dan fisik. Bahkan, apabila menetap sampai usia dewasa mereka akan rentan terhadap masalah adaptasi, menyalahgunakan obat terlarang, sulit mendapatkan pekerjaan, dan dapat berkembang menjadi gangguan kepribadian antisosial. ${ }^{21}$

Secara umum permasalahan pokok pendidikan, yaitu:

1. Masalah pemerataan pendidikan; dalam melaksanakan fungsinya sebagai wahana untuk memajukan bangsa dan kebudayaan nasional, pendidikan nasional diharapkan dapat menyediakan kesempatan yang seluas-luasnya bagi seluruh warga negara Indonesia untuk memperoleh pendidikan. Masalah pemerataan pendidikan adalah persoalan bagaimana sistem pendidikan dapat menyediakan kesempatan yang seluas-luasnya kepada seluruh warga negara untuk memperoleh pendidikan, sehingga pendidikan ini menjadi wahana bagi pembangunan sumber daya manusia untuk menunjang pembangunan. Masalah pemerataan pendidikan timbul apabila masih banyak warga negara khususnya anak usia sekolah yang tidak dapat ditampung di dalam sistem atau lembaga pendidikan karena kurangnya fasilitas pendidikan yang tersedia.

2. Masalah mutu pendidikan; mutu pendidikan dipermasalahkan jika hasil pendidikan belum mencapai taraf seperti yang diharapkan. Penetapan mutu hasil pendidikan pertama dilakukan oleh lembaga penghasil sebagai produsen tenaga terhadap calon luaran dengan sistem sertifikasi. Selanjutnya jika luaran tersebut terjun ke lapangan kerja penilaian dilakukan oleh lembaga pemakai sebagai konsumen tenaga dengan sistem unjuk kerja. Jadi mutu pendidikan pada akhirnya dilihat dari kualitas keluarannya. Jika tujuan pendidikan nasional dijadikan kriteria maka pertanyaannya adalah: apakah keluaran dari suatu sistem pendidikan menjadi pribadi yang bertakwa, mandiri dan berkarya, anggota masyarakat yang sosial dan bertanggung jawab, warga negara yang cinta kepada tanah air dan memiliki rasa kesetiakawanan sosial.

3. Masalah efisiensi pendidikan; hal ini mempersoalkan bagaimana suatu sistem pendidikan mendayagunakan sumber daya yang ada untuk mencapai tujuan pendidikan. Jika penggunaannya hemat dan tepat sasaran dikatakan efisien nya tinggi. Jika terjadi yang sebaliknya maka efisiensinya berarti rendah.

4. Masalah relevansi pendidikan; keluaran pendidikan diharapkan dapat mengisi semua sektor pembangunan yang beraneka ragam seperti sektor produksi, sektor jasa, dan sektor lainnya. Baik dari segi jumlah maupun dari segi kualitas. Jika sistem pendidikan menghasilkan keluaran yang dapat mengisi semua sektor pembangunan baik yang aktual maupun yang potensi dengan memenuhi kriteria

${ }^{20}$ Jenny Ghichara, Mengatasi Perilaku Buruk Anak, (Jakarta: Kawan Pustaka, 2006), h.1

21 Aini Mahabbat, Pola Perilaku Bermasalah Dan Rancangan Intervensi Pada Anak Tunalaras Tipe Gangguan Perilaku (Conduct Disorder) Berdasarkan Functional Behavior Assessment, Jurnal Dinamika Pendidikan Vol. 01 (21) Tahun 2014, h.3 
yang dipersyaratkan oleh lapangan kerja, maka relevansi pendidikan dianggap tinggi. $^{22}$

\section{Tahap perkembangan Remaja}

Tahap Perkembangan Remaja (Adolescence), Piaget membagi tahap perkembangan kognitif meliputi empat tahapan, yaitu:

1. Tahap Sensorimotorik (2 Tahun) Pada tahap ini, anak mengkonstruksikan pemahaman mengenai dunia dengan mengkoordinasikan pengalaman sensoris (seperti melihat dan mendengar) dengan tindakan fisik-motorik karena hal tersebut disebut dengan sensori motorik.

2. Tahap Pra-operasional (2-7 Tahun) Pada tahap ini anak mulai mempresentasikan dunia dengan kata-kata, cerita, dan gambar-gambar.

3. Tahap Operasional Konkrit (7-11 Tahun) Pada tahap ini anak, anak dapat melakukan operasi dan penalaran logis, mengaitkan pemikiran intuitif, sepanjang penalaran dapat diaplikasikan pada contoh khusus atau konkrit.

4. Tahap Operasional Formal (11-15 Tahun) Pada tahap ini, anak mulai bergerak melebihi dunia pengalaman yang aktual dan konkrit dan berfikir lebih abstrak serta logis. ${ }^{23}$

Piaget dalam penelitiannya mengenai perkembangan anak mengemukakan bahwa perkembangan anak dibagi menjadi tiga, yaitu perkembangan kognitif, psikomotorik, dan afektif. Kognisi adalah pengertian yang luas mengenai berpikir dan mengamati, jadi tingkah laku-tingkah laku yang mengakibatkan orang memperoleh pengetahuan atau yang dibutuhkan untuk menggunakan pengetahuan. ${ }^{24}$

\section{Hasil Penelitian dan Pembahasan}

\section{A. Hasil Penelitian}

\section{Analisis Manajerial Kepala Madrasah dalam Menangani Perilaku Siswa bermasalah di MTs Al-Hikmah Mogutat Kotamobagu}

Peran kepemimpinan Kepala Sekolah dalam menangani perilaku siswa yang bermasalah di MTs Al-Hikmah Mogutat Kotamobagu. berdasarkan tujuan pada penelitian ini yaitu untuk menganalisis kepemimpinan kepala MTs Al-Hikmah Mogutat Kotamobagu dalam menangani perilaku siswa yang bermasalah.

Wawancara dengan Kepala MTs Al-Hikmah Mogutat Kotamobagu, yaitu: "Kepala madrasah menunggu penyelesaian, jika tidak ada penyelesaian selanjutnya, kemudian kepala madrasah meminta rapat bersama untuk mencarikan solusi-solusi yang tepat, melakukan diskusi dengan guru kelas dan guru bimbingan konseling". ${ }^{25}$

Berdasarkan hasil wawancara di atas menunjukkan bahwa kepala MTs Al-Hikmah Mogutat Kotamobagu selalu melakukan pengawasan terhadap siswa bermasalah, dan

\footnotetext{
${ }^{22}$ Umar Tirtarahardja dan La Sulo, Pengantar Pendidikan (Jakarta: Rineke Cipta, 2005), h.227

${ }^{23}$ J. W Santrock, Psikologi Pendidikan (Jakarta : Kencana, 2008), h. 50

${ }^{24}$ J. W Santrock, Psikologi Pendidikan, h. 51

${ }^{25}$ Wawancara dengan Kepala MTs Al-Hikmah Mogutat Kotamobagu, tanggal 23 Juli 2018
} 
penanganan dari guru tersebut. Kemudian kepala madrasah membuat rapat internal guru, yang bertujuan untuk mencarikan solusi dari permasalahan tersebut.

Wawancara dengan wakil kepala kesiswaan di MTs Al-Hikmah Mogutat Kotamobagu: "Dapat saya jelaskan bapak kepala madrasah memiliki tipe yang sangat bersahaja dan humanis. Saat saya menjadi wakil kepala kesiswaan dapat saya jelaskan perilaku anak madrasah perilaku yang menyimpang masih tergolong sedikit. Bapak kepala madrasah apabila ada masalah masih diserahkan pada wakil kepala kesiswaan kecuali ada yang urgen, maka beliau menanyakan dan memberikan solusi". ${ }^{26}$

"Dapat saya jelaskan bapak kepala madrasah memiliki tipe yang sangat bersahaja dan humanis. Saat saya menjadi wakil kepala kesiswaan dapat saya jelaskan perilaku anak madrasah perilaku yang menyimpang masih tergolong sedikit. Bapak kepala madrasah apabila ada masalah masih diserahkan pada wakil kepala kesiswaan kecuali ada yang urgen, maka beliau menanyakan dan memberikan solusi". ${ }^{27}$

Dari wawancara di atas tipe kepemimpinan sangat bersahaja dan humanis, banyak perilaku siswa yang bermasalah di MTs Al-Hikmah Mogutat Kotamobagu, di mana penyelesaiannya diserahkan pada bidang kesiswaan, namun pada permasalahan yang urgen maka kepala madrasah turut dalam penyelesaian siswa yang bermasalah.

\section{Analisis Kebijakan Penanganan Siswa yang Bermasalah di MTs Al-Hikmah Mogutat Kotamobagu}

Berdasarkan hasil wawancara dengan kepala madrasah dan guru di MTs Al-Hikmah Mogutat Kotamobagu diperoleh hasil:

Kepala madrasah MTs Al-Hikmah Mogutat Kotamobagu, yaitu:

"Saya melihat bahwa pola penanganan siswa yang bermasalah di Kotamobagu sudah baik, di mana guru selalu memperhatikan siswa-siswa yang dianggap nakal. Selalu memberikan laporan terhadap hasil pekerjaan siswa. sehingga saya tahu mana siswa yang nakal dan mana yang tidak nakal". ${ }^{28}$

"Banyak permasalahan yang seringkali saya temukan di dalam kelas, terutama kelas menjadi ribut, jika belum ada guru di dalam kelas, bahkan ada yang adu mulut dan adu pukul ketika tidak ada guru. untuk itu saya selalu memberikan instruksi agar selalu memberikan laporan tentang perkembangan siswa di dalam kelas". ${ }^{29}$

Pola penanganan siswa yang bermasalah di Kotamobagu sudah baik, indikasinya guru memperhatikan siswa-siswa yang mempunyai perilaku bermasalah. Guru selalu memberikan laporan terhadap siswa yang bermasalah di madrasah. Permasalahan yang seringkali ditemukan dalam kelas, suasana kelas menjadi ribut ketika tidak ada guru, bahkan ada yang adu mulut dan adu pukul ketika tidak ada guru

Hasil wawancara dengan wakil kepala bidang kesiswaan di MTs Al-Hikmah Mogutat Kotamobagu menyatakan bahwa: "Terlambat ke madrasah, hal ini seringkali terjadi di

\footnotetext{
24 Juli 2018

${ }^{27}$ Wawancara dengan Wakil Kepala bidang Sarana di MTs Al-Hikmah Mogutat Kotamobagu, tanggal 24 Juli 2018

${ }^{28}$ Wawancara dengan Kepala MTs Al-Hikmah Mogutat Kotamobagu, tanggal 23 Juli 2018

${ }^{29}$ Wawancara dengan Kepala MTs Al-Hikmah Mogutat Kotamobagu, tanggal 23 Juli 2018
}

${ }^{26}$ Wawancara dengan Wakil Kepala bidang Sarana di MTs Al-Hikmah Mogutat Kotamobagu, tanggal 
madrasah, untuk itu diperlukan penanganan secara intensif, agar supaya dapat mengurangi keterlambatan untuk datang ke madrasah". "Masalah pada guru mata pelajaran, di mana guru yang bersangkutan yang menangani bila tidak selesai kemudian di serahkan ke wali kelas kemudian perwalian yang menangani dengan cara memanggil siswa yang bersangkutan lalu memberikan solusi kemudian ada kunjungan ke rumah". ${ }^{31}$

"Masalah siswa: tentang kehadiran siswa tidak aktif hadir di sekolah sehingga tidak naik kelas tidak capai target $60-70 \%$ kehadiran dari siswa bersangkutan dan penyebabnya masalah ekonomi orang tua. Yang tidak naik kelas pada kelas 8 ada 3 orang an kelas 9 ada 2 orang". ${ }^{32}$

Dari uraian di atas menunjukkan bahwa salah satu permasalahan siswa adalah datang terlambat ke madrasah. Perlu ada penanganan terhadap kurang disiplinnya siswa di madrasah. Pola penanganan siswa yang bermasalah mulai dari tingkatan guru, kemudian memanggil orang tua dan melibatkan kepala madrasah, sampai pada kunjungan ke rumah dari siswa yang bersangkutan.

Wawancara dengan guru di MTs Al-Hikmah Mogutat Kotamobagu, yaitu:“Ada juga yang cepat menikah terjadi di kelas 9, solusinya yaitu sudah di kunjungi kepala madrasah, wali kelas, dan panitia ujian, akan tetapi dari pribadi dan keluarga sudah mengambil keputusan untuk tidak sekolah dan itu semua merupakan pengaruh dari faktor lingkungan". 33، Ada siswa yang melawan guru: solusinya harus dengan cermat, sehingga tidak sampai drop out dari madrasah. Siswa yang mengkonsumsi minuman keras, solusinya: dinasihati dengan mengayomi dilindungi sehingga di siswa jadi normal kembali, terakhir di suruh sholat, siswa tersebut sudah naik kelas 9 lalu di berikan kembali bimbingan ataupun pembinaan". "34"Ada juga siswa masih jam belajar kemudian ke kantin, itu terjadi pada saat pergantian jam (09.00 s/d 10.00), karena keterlambatan guru masuk kelas, sehingga siswa mengambil kesempatan keluar kelas. solusinya: guru harus awal masuk kelas, untuk memberikan pembimbingan ataupun pembinaan kepada siswa". ${ }^{35}$

Dari hasil wawancara di atas, ada juga persoalan yang berat di mana ada siswa yang cepat menikah, sehingga tidak dapat mengikuti ujian di madrasah, dan hal ini dipengaruhi oleh faktor lingkungan tempat di mana siswa tersebut berada. Ada siswa yang melawan terhadap guru, minum minuman keras, namun usaha-usaha yang dilakukan oleh pihak madrasah yaitu memberikan bimbingan, dan mengarahkan untuk Sholat berjama'ah.

\section{Analisis Pembagian Tugas Dalam Penanganan Siswa Bermasalah di MTs Al- Hikmah Mogutat Kotamobagu}

Wawancara dengan Kepala MTs Al-Hikmah Mogutat Kotamobagu: "Sebagai kepala Madrasah saya selalu memberikan instruksi kepada guru BK maupun guru kelas untuk melakukan pengamatan terhadap siswa yang bermasalah. Membuat laporan untuk penanganan siswa bermasalah tersebut. saya memberikan tugas kepada guru untuk melakukan pengamatan terhadap siswa bermasalah. Penanganannya bertahap mulai dari pemberiah hukuman ringan

${ }^{30}$ Wawancara dengan Wakil Kepala bidang Kesiswaan di MTs Al-Hikmah Mogutat Kotamobagu, tanggal 23 Juli 2018

31 Wawancara dengan Wakil Kepala bidang Kesiswaan di MTs Al-Hikmah Mogutat Kotamobagu, tanggal 23 Juli 2018

${ }^{32}$ Wawancara dengan Wakil Kepala bidang Kesiswaan di MTs Al-Hikmah Mogutat Kotamobagu, tanggal 23 Juli 2018

${ }^{33}$ Wawancara dengan guru inisial SP di MTs Al-Hikmah Mogutat Kotamobagu, tanggal 25 Juli 2018

${ }^{34}$ Wawancara dengan guru inisial SP di MTs Al-Hikmah Mogutat Kotamobagu, tanggal 25 Juli 2018

${ }^{35}$ Wawancara dengan guru inisial SP di MTs Al-Hikmah Mogutat Kotamobagu, tanggal 25 Juli 2018 
sampai hukuman berat. Hukuman ringan hanya berupa bimbingan dan peringatan saja, hukuman berat berupa skorsing dan pemanggilan orang tua di madrasah".

Dari wawancara di atas terlihat kepala madrasah sudah melakukan pembagian kerja terhadap guru BK maupun guru kelas, dalam hal melakukan pengamatan terhadap siswasiswa yang bermasalah, serta menyusun laporan-laporan harian.

Pembebanan tugas untuk penanganan siswa yang bermasalah dilakukan secara sistematis, mulai bimbingan guru, guru BK, kepala sekolah sampai pada pemanggilan orang tua. Pembinaan-pembinaan tersebut dilakukan oleh madrasah agar supaya dapat mengatasi perilaku-perilaku bermasalah siswa di MTs Al-Hikmah Mogutat Kotamobagu.

Wawancara dengan Wakil kurikulum di MTs Al-Hikmah Mogutat Kotamobagu: “Tipe kepemimpinan kepala madrasah MTs Al-Hikmah Mogutat Kotamobagu sangat tegas dalam mengambil keputusan, sehingga guru-guru harus siap untuk menindaklanjut instruksi dari kepala madrasah". "Untuk perilaku siswa yang menyimpang yang sangat terlihat yaitu banyaknya siswa yang saling mengejek atau menyebut nama orang tua, hal ini menjadi awal terjadinya perkelahian". ${ }^{37}$ "Dalam hal penyelesaian siswa yang bermasalah semua berperan mulai dari guru melakukan bimbingan atau nasihat kepada siswa, wakil kepala madrasah yang memberikan saran guru, kepala madrasah melakukan koordinasi dengan guru dan orang tua siswa di MTs Al-Hikmah Mogutat Kotamobagu". 38

Berdasarkan hasil wawancara di atas kepala MTs Al-Hikmah Mogutat Kotamobagu sangat tegas dalam mengambil keputusan, sehingga guru harus menindaklanjuti dari hasil keputusan dari pimpinan. Indikasi siswa yang bermasalah yaitu antara siswa saling mengejek dengan menyebut nama orang tua, dan biasanya permulaan dari perkelahian adalah saling mengejek orang tua. Untuk penyelesaian siswa bermasalah, semua berperan mulai dari kepala, wakil kepala, guru MTs Al-Hikmah Mogutat Kotamobagu, juga orang tua siswa.

\section{B. Pembahasan}

Di MTs Al-Hikmah Mogutat Kotamobagu merupakan salah satu madrasah swasta yang ada di Kotamobagu, mengalami progres yang baik. Walaupun memang madrasah swasta yang dikatakan masih baru akan tetapi perkembangannya sangat baik. Sejak didirikan dari tahun 2014 sampai tahun 2018 sudah banyak hal yang dikembangkan oleh manajemen MTs AlHikmah Mogutat Kotamobagu. Pengembangan kompetensi guru melalui pendidikan maupun pelatihan yang sesuai dengan kompetensi dari guru ataupun tenaga kependidikan di MTs AlHikmah Mogutat Kotamobagu. Pembangunan fisik yang dilakukan secara terus menerus sehingga semakin hari semakin baik, terutama penambahan ruang belajar.

\footnotetext{
${ }^{36}$ Wawancara dengan Wakil Kepala bidang Kurikulum di MTs Al-Hikmah Mogutat Kotamobagu, tanggal 24 Juli 2018

37 Wawancara dengan Wakil Kepala bidang Kurikulum di MTs Al-Hikmah Mogutat Kotamobagu, tanggal 24 Juli 2018

${ }^{38}$ Wawancara dengan Wakil Kepala bidang Kurikulum di MTs Al-Hikmah Mogutat Kotamobagu, tanggal 24 Juli 2018
} 


\section{Analisis Manajerial Kepala Madrasah dalam Menangani Siswa Bermasalah di MTs Al-Hikmah Mogutat Kotamobagu}

Kepemimpinan merupakan faktor penting dalam meningkatkan kualitas atau mutu pendidikan yang ada di madrasah. Untuk itu madrasah perlu memiliki pemimpin yang dapat memberdayakan semua sumber daya yang ada di madrasah dengan baik.

Begitu juga di MTs Al-Hikmah Mogutat Kotamobagu peran seorang pemimpin merupakan suatu yang penting. Di mana pemimpin yang dapat mengidentifikasi permasalahan dan mampu membuat solusi-solusi yang efektif dengan melibatkan semua unsur-unsur yang ada di madrasah. permasalahan yang di hadapi oleh MTs Al-Hikmah Mogutat Kotamobagu tentunya tidak lepas dari permasalahan siswa itu sendiri.

Untuk mengatasi permasalahan siswa tentunya tidak lepas dari kemampuan seluruh unsur-unsur yang ada di madrasah untuk mengatasi permasalahan tersebut. Jika seorang pemimpin dalam hal ini kepala madrasah dapat menciptakan solusi-solusi yang efektif dengan melibatkan para guru dan pengawas.

Kepemimpinan di MTs Al-Hikmah Mogutat Kotamobagu dalam menangani siswa bermasalah yaitu:

a. Menginstruksikan kepada seluruh guru untuk melaporkan semua permasalahan berkaitan dengan siswa di MTs Al-Hikmah Mogutat Kotamobagu

b. Mengidentifikasi semua laporan-laporan berkaitan dengan permasalahan siswa di madrasah

c. Memanggil beberapa orang guru untuk berdiskusi berkaitan dengan permasalahan siswa

d. Memberikan beberapa instruksi untuk penanganan siswa yang bermasalah tersebut

e. Jika permasalahan tidak dapat diatasi oleh guru maka kepala madrasah turut mengatasi permasalahan tersebut dengan melibatkan semua pihak yang terlibat dalam permasalahan tersebut.

Jadi penanganan permasalahan siswa oleh Kepala Madrasah menunjukkan tanggung jawab yang sangat baik, dan selalu melakukan pengawasan dan evaluasi terhadap permasalahan tersebut.

Peran kepala MTs Al-Hikmah Mogutat Kotamobagu lebih cenderung memberikan bimbingan terhadap siswa, dan memberikan solusi-solusi yang efektif untuk mengatasi permasalahan tersebut. Kepala sekolah atau madrasah harus berusaha menanamkan, memajukan dan meningkatkan sedikitnya empat macam nilai, yaitu:

1) Pembinaan mental, yaitu pembinaan para tenaga kependidikan tentang hala-hal yang berkaitan dengan sikap batin dan watak.

2) Pembinaan moral, yaitu membina para tenaga kependidikan tentang hal-hal yang berkaitan dengan ajaran baik buruk mengenai suatu perbuatan, sikap dan kewajiban sesuai dengan tugas masing-masing tenaga kependidikan.

3) Pembinaan fisik, yaitu pembinaan para tenaga kependidikan tentang hal-hal yang berkaitan dengan kondisi jasmani atau badan, kesehatan atau penampilan mereka. 
4) Pembinaan artistik, yaitu membina tenaga kependidikan tentang hal-hal yang berkaitan dengan kepekaan manusia terhadap seni dan keindahan. ${ }^{39}$

Dari uraian di atas menunjukkan bahwa apa yang dilakukan oleh kepala MTs Al-Hikmah Mogutat Kotamobagu sudah sesuai dengan uraian di atas. Kepala sekolah adalah seorang fungsional guru yang diberi tugas untuk memimpin suatu sekolah di mana diselenggarakan proses belajar mengajar, atau tempat di mana terjadi interaksi antara guru yang memberi pelajaran dan murid yang menerima pelajaran. Menurut Mulyono kemajuan sekolah akan lebih penting bila orang memberikan perhatian pada kiprah kepala madrasah karena alasanalasan sebagai berikut:

a. Kepala sekolah merupakan tokoh sentral pendidikan. Hal ini dikarenakan bahwa kepala sekolah sebagai fasilitator bagi pengembangan pendidikan, sebagai pelaksana suatu tugas yang syarat dengan harapan dan pembaharuan.

b. Kepala sekolah adalah sebagai suatu komunitas pendidikan yang membutuhkan seseorang pemimpin untuk mendayagunakan potensi yang ada dalam sekolah. ${ }^{40}$

Dari uraian di atas jika dikaitkan dengan peran kepala MTs Al-Hikmah Mogutat Kotamobagu, ternyata ada kesamaannya. Hal ini terlihat dari aktivitas keseharian dari kepala madrasah. Kepemimpinan terlihat memegang peranan penting dalam pengambilan keputusankeputusan, para guru selalu memberikan laporan terhadap semua kegiatan-kegiatan baik itu di dalam kelas maupun di luar kelas. Berbagai laporan tersebut langsung di respon oleh kepala madrasah, sehingga permasalahannya tidak berlarut-larut.

Permasalahan berkaitan dengan kenaikan kelas, di mana ada yang naik murni ataupun naik bersyarat (harus menyelesaikan beberapa kompetensi pada mata pelajaran), di samping itu siswa yang tidak naik kelas dikarenakan kehadiran tidak mencapai 60-60\%.

Kepala MTs Al-Hikmah Mogutat Kotamobagu sangat tegas dalam mengambil keputusan, sehingga guru harus menindaklanjuti dari hasil keputusan dari pimpinan. Indikasi siswa yang bermasalah yaitu antara siswa saling mengejek dengan menyebut nama orang tua, dan biasanya permulaan dari perkelahian adalah saling mengejek orang tua. Untuk penyelesaian siswa bermasalah, semua berperan mulai dari kepala, wakil kepala, guru MTs Al-Hikmah Mogutat Kotamobagu, juga orang tua siswa.

\section{Analisis Kebijakan Penanganan Siswa Bermasalah di MTs Al-Hikmah Mogutat Kotamobagu}

Menurut Cohen dalam Aini Mahabbat anak yang bermasalah merupakan anak dengan gangguan perilaku di mana sulit untuk diberi arahan pembelajaran, sering membantah guru, menolak tugas, dan melanggar peraturan. Selain itu mereka bermasalah dalam hubungan sosial dengan guru dan teman, dengan perilaku berupa tidak sopan terhadap guru; membantah; menentang; mengganggu teman; berkelahi; dan berkerja sama melakukan kenakalan. $^{41}$

39 Mulyasa, Menjadi Kepala Sekolah Professional Dalam Konteks Menyukseskan MBSdan KBK.( Bandung: PT Remaja Rosada Karya, 2003), h.98

${ }^{40}$ Cut Zahri Harun, Manajemen Sumber Daya Pendidikan (Yogyakarta: Pena Persada, 2009), h.28.

41 Aini Mahabbat, Pola Perilaku Bermasalah Dan Rancangan Intervensi Pada Anak Tunalaras Tipe Gangguan Perilaku (Conduct Disorder) Berdasarkan Functional Behavior Assessment, Jurnal Dinamika Pendidikan Vol. 01 (21) Tahun 2014, h.3 
Menurut Burke dalam Aini Mahabbat, anak yang bermasalah adalah anak dengan gangguan perilaku sulit berempati, sulit mengidentifikasi perilaku positif dalam hubungan interpersonal dan sosial, sulit berinisiatif melakukan kontak sosial sesuai usia, dan cenderung mengatasi masalah dengan cara berperilaku agresif. ${ }^{42}$

Pola penanganan yang dilakukan oleh MTs Al-Hikmah Mogutat Kotamobagu dalam menangani siswa bermasalah harus memberikan pengaruh yang positif terhadap perbaikan dari siswa yang bermasalah tersebut. Untuk itu kita terlebih dahulu harus mengetahui penyebab kenapa terjadi permasalahan terhadap siswa tersebut.

Faktor-faktor penyebab kenakalan siswa di MTs Al-Hikmah Mogutat Kotamobagu, yaitu:

a. Masalah keluarga, seperti: perceraian orang tua, sehingga anak suka marah dan merasa dikucilkan oleh teman-temannya, kurangnya penanaman nilai-nilai keagamaan sejak dini pada anak, sehingga anak suka mengambil hak milik orang lain, dan rendahnya pendapatan orang tua, sehingga anak merasa rendah diri dalam berinteraksi dengan siswa yang lain.

Sebuah penelitian yang dilakukan oleh John Onyango Omboto dkk, hasil penelitian mereka meneliti tentang faktor-faktor penyebab kenakalan remaja adalah faktor keluarga, yakni rendahnya pendapatan keluarga. Berbagai pengamatan menunjukkan bahwa sebagian besar pemuda yang dalam kejahatan karena kemiskinan, hal tersebut yang mendorong mereka untuk melakukan jenis pelanggaran yang dikategorikan sebagai kenakalan remaja. Terungkap juga pada kenakalan remaja terjadi karena sebagian besar anak-anak itu dari keluarga disfungsional. Beberapa anak laki-laki telah yatim piatu tanpa wali sebelum penangkapan mereka, yang lain memiliki satu atau bercerai orang tua, dan beberapa memiliki orang tua di perbedaan utama, lalu orang tua atau wali yang pecandu alkohol yang tidak bisa menjadi contoh orang tua yang baik. ${ }^{43}$

Dari penelitian di atas terdapat persamaan dan perbedaan dengan hasil penelitian. Persamaannya adalah kedua penelitian membahas tentang sumber-sumber terjadinya kenakalan remaja atau siswa seperti faktor rendahnya pendapatan keluarga. Perbedaannya dalam penelitian terdahulu membahas faktor-faktor penyebab kenakalan remaja tidak hanya dari rendahnya pendapatan keluarga atau kemiskinan, tetapi sebagian besar pemuda dalam melakukan kejahatan atau kenakalan remaja karena faktor disfungsional keluarga atau tidak berfungsinya peran keluarga, di samping itu juga terdapat beberapa anak laki-laki telah yatim piatu tanpa wali sebelum penangkapan mereka, yang lain memiliki orang tua tunggal atau bercerainya orang tua, dan beberapa orang memiliki orang tua dengan berbeda pandangan, lalu orang tua atau wali yang pecandu alkohol yang tidak bisa menjadi contoh orang tua yang baik.

b. Penyebab kenakalan siswa yang bersumber dari lingkungan, antara lain salah pergaulan di lingkungan rumah tempat tinggal dan salah memilih teman di lingkungan sekolah. Faktor kenakalan siswa yang bersumber dari lingkungan rumah tempat tinggal yang

${ }^{42}$ Aini Mahabbat, Pola Perilaku Bermasalah Dan Rancangan Intervensi Pada Anak Tunalaras Tipe Gangguan Perilaku (Conduct Disorder) Berdasarkan Functional Behavior Assessment, Jurnal Dinamika Pendidikan Vol. 01 (21) Tahun 2014, h.3

43 John Onyango Omboto, Gerald O. Ondiek, Odhiambo Odera, dan Mary Evelyn Ayugi, Factors Influencing Youth Crime And Juvenile Delinquency, International Journal of Research In Social Sciences, Vol. XX (28) Tahun 2015 
terdapat dalam diri siswa antara lain adalah sikap egois yang dimiliki oleh siswa. Dimana orang tua harus mengikuti semua keinginan siswa dan apabila keinginan tersebut tidak terpenuhi maka siswa akan menunjukkan ekspresi tidak suka dengan melakukan kenakalan-kenakalan dengan harapan orang tua akan menuruti kemauan mereka. Di MTs Al-Hikmah Mogutat Kotamobagu terdapat beberapa siswa yang melakukan kenakalan dengan alasan sebagai wujud protes kepada orang tuanya yang tidak mau menuruti kemauan mereka seperti meminta handphone baru, uang, sepatu baru dan lain-lain.

Menurut Asmawati Suhid, Abdul Rahmah Md. Aroff, dan Norliana Kamal, meskipun faktor yang berhubungan dengan sekolah (seperti guru, teman sebaya, dan siswa sendiri) relatif tidak terlalu kuat dalam menyebabkan siswa menjadi tidak masuk sekolah, otoritas sekolah masih harus mengatasi item yang memiliki mean skor lebih dari 3,0. Oleh karena itu, meningkatkan lingkungan sekolah (seperti ukuran kelas dan peraturan sekolah yang wajar) sehingga suasana belajar kondusif untuk belajar harus diberikan prioritas dalam mengatasi kenakalan siswa seperti masalah membolos. ${ }^{44}$

Berdasarkan penelitian di atas terdapat persamaan dan perbedaan dengan hasil penelitian. Persamaannya adalah kedua penelitian membahas tentang sumber-sumber terjadinya kenakalan remaja yang berasal dari lingkungan sekolah. Perbedaannya adalah dalam penelitian di atas membahas tentang kenakalan remaja yang bersumber dari lingkungan tempat tinggal saja.

c. Mengenai faktor lingkungan ini mencakup lingkungan keluarga, masyarakat maupun lingkungan sekolah, seperti orang tua atau saudara yang pernah terlibat dengan tindakan kriminal, selain itu salah pergaulan di lingkungan rumah tempat tinggal, salah memilih teman di lingkungan madrasah.

d. Adapun faktor yang ketiga yakni melalui media elektronik, antara lain munculnya acaraacara televisi yang memperlihatkan kekerasan, munculnya film-film yang kurang mendidik sehingga remaja dengan mudahnya meniru adegan-adegan atau kegiatan yang dilihatnya dapat menunjukkan eksistensi dirinya di masyarakat, tetapi sebenarnya hal itu merupakan penyimpangan yang dilakukan remaja. Televisi, video, film dan sebagainya ikut berperan merusak mental remaja, padahal mayoritas ibu-ibu yang sibuk menyuruh anaknya menonton televisi sebagai upaya menghindari tuntutan anak yang tak ada habisnya. Sebuah penelitian lapangan yang pernah dilakukan di Amerika menunjukkan bahwa film-film yang memamerkan tindak kekerasan sangat berdampak buruk pada tingkah laku remaja.

Pola penanganan Siswa yang bermasalah di MTs Al-Hikmah Mogutat Kotamobagu, yaitu:

Kenakalan siswa yang terjadi di lingkungan MTs Al-Hikmah Mogutat Kotamobagu terbagi menjadi dua kelompok yaitu kenakalan yang sifatnya ringan seperti membolos, bercerita atau ramai ketika jam pelajaran berlangsung, merokok, tidak mengerjakan pekerjaan rumah (PR), tidak memakai ikat pinggang dan kaos kaki, sering terlambat datang ke sekolah, saling mengejek orang tua, menyontek, dan berpacaran. Kenakalan siswa yang sifatnya berat adalah kenakalan siswa yang sampai pada pelanggaran hukum seperti tawuran, mencuri,

44 Asmawati Suhid, Abdul Rahmah Md. Aroff, dan Norliana Kamal, "Factors Causing Student Absenteeism According To Peers" Jurnal Faculty of Education Studies University Putra Malaysia, Vol. 3 (24) Tahun 2012, h.2 
mengkonsumsi narkoba dan minuman keras. Berdasarkan hasil wawancara “...anak-anak yang melakukan pelanggaran berat seperti narkoba dan minuman keras kurang lebih 10 orang, dan pelanggaran ringan seperti datang terlambat secara rata-rata 4 s/d 8 orang setiap hari, merokok dan nongkrong di kantin berjumlah 12 orang....".

Di MTs Al-Hikmah Mogutat Kotamobagu, penanganan yang dilakukan sekolah adalah dengan memberikan teguran dan nasihat kepada siswa yang bermasalah, memberikan perhatian khusus kepada siswa yang bersangkutan dan menghubungkan orang tua siswa. Selain itu pihak sekolah juga melakukan penanganan dengan pendekatan kasus perkasus secara individual.

\section{Analisis Pembagian Tugas Penanganan Siswa Bermasalah di MTs Al-Hikmah Mogutat Kotamobagu}

Pembagian tugas dalam penanganan siswa bermaslaah di MTs Al-Hikmah Mogutat Kotamobagu, mulai dari instruksi Kepala Madrasah terhadap guru BK dan guru kelas agar supaya melakukan pengamatan terhadap siswa-siswa yang bermasalah, sebagaimana wawancara dengan Kepala Madrasah “... saya selalu menginstruksikan kepada guru BK dan guru kelas untuk mengawasi para siswa yang bermasalah..." di samping itu kepala madrasah selalu menginstruksikan kepada orang tua dari siswa yang bermasalah tersebut, agar supaya turut serta untuk mengawasi dan pembinaan terhadap anaknya sebagaimana wawancara dengan kepala madrasah “...pelibatan orang tua dalam penanganan siswa yang bermasalah agar selalu mengawasi dan membimbing anaknya...". Jadi pembagian tugas sudah jelas yaitu melakukan pendekatan secara kolektif, di mana kepala madrasah dan guru mempunyai peran di madrasah, sedangkan orang tua harus berperan di rumah.

Menurut Nurkumala Sari peran guru dan orang tua dalam mengembangkan minat dan bakat anak adalah guru membantu siswa di sekolah dalam membimbing, mengarahkan sertamelatih siswa. Orang tua melanjutkan peran dari guru di sekolah yaitu memperhatikan perkembangan minat dan bakat anak tunagrahita di rumah. ${ }^{45}$

Pola kepemimpinan kepala madrasah tidak sekedar melaksanakan tugas rutin yang sama saja dari hari ke hari berikutnya. Semua sudah ditentukan standarnya, dan kalau kinerja sudah sesuai standar maka bereslah segalanya. Kepala madrasah juga memerlukan standar kinerja, tetapi bedanya standar ini bersifat dinamis yang selalu bisa ditingkatkan, sehingga memungkinkan terjadinya peningkatan mutu secara berkelanjutan.

\section{Penutup}

\section{Kesimpulan}

1. Kepemimpinan Manajerial kepala madrasah dalam menangani siswa perilaku bermasalah di MTs Al-Hikmah Mogutat Kotamobagu, di mana kepala madrasah selalu menginstruksikan kepada guru untuk memberikan laporan perkembangan anak termasuk aspek sikap, melakukan identifikasi terhadap permasalahan siswa, dan menciptakan solusi yang efektif dalam menangani permasalahan siswa.

2. Kebijakan penanganan siswa berperilaku bermasalah di MTs Al-Hikmah Mogutat Kotamobagu ada beberapa cara yaitu: melakukan bimbingan terhadap siswa, melibatkan

${ }^{45}$ Nurkumala Sari Br. Lubis, Peran Guru Dan Orang Tua Dalam Mengembangkan Minat Dan Bakat Anak Tunagrahita Di Slb Negeri Pembina Yogyakarta (Tesis Program Studi Pendidikan Sosiologi Jurusan Pendidikan Sejarah Fakultas Ilmu Sosial Universitas Negeri Yogyakarta, 2012) 
Journal of Islamic Education Policy Vol. 4 No. 2 Juli - Desember 2019

orang tua, guru, kepala madrasah dalam penanganan anak berperilaku menyimpang. Guru membuat laporan-laporan perkembangan siswa terutama perkembangan perilaku siswa selama proses pembelajaran.

3. Pembagian tugas penanganan siswa perilaku bermasalah di MTs Al-Hikmah Mogutat Kotamobagu, di mana Kepala madrasah selalu melibatkan baik itu unsur guru dan orang tua dalam menangani permasalahan siswa di MTs Al-Hikmah Mogutat Kotamobagu. Guru melakukan penanganan ketika berada di madrasah, sedangkan orang tua melanjutkan penanganan siswa bermasalah ketika berada di rumah.

\section{Implikasi}

1. Penanganan yang tepat sesuai dengan karakteristik siswa, maka berimplikasi pada perbaikan sikap siswa di MTs Al-Hikmah Mogutat Kotamobagu

2. Peran kepemimpinan dalam memberdayakan guru untuk penanganan siswa perilaku bermasalah, maka berimplikasi pada perbaikan perilaku siswa bermasalah di MTs AlHikmah Mogutat Kotamobagu.

\section{Rekomendasi}

1. MTs Al-Hikmah Mogutat Kotamobagu.perlu melakukan strategi pencegahan (preventif) dengan melakukan pengawasan yang ketat dan segera menindaklanjuti ketika ada siswa yang mempunyai permasalahan, implikasinya permasalahan tersebut dapat cepat di selesaikan.

2. Kepala madrasah harus membuat program-program yang efektif, serta melibatkan semua pihak yang ada di madrasah, implikasinya dapat mencegah terjadinya permasalahan terhadap siswa, serta dengan adanya pelibatan semua pihak di madrasah maka akan mempermudah penyelesaian masalah di MTs Al-Hikmah Mogutat Kotamobagu.

\section{Daftar Pustaka}

Dalyono, Psikologi Pendidikan, Jakarta: Rineka Cipta, 2009

Darwis, Abu, Pengubahan Perilaku Menyimpang Murid SD, Jakarta: Departemen Pendidikan Nasional Direktorat jendral Pendidikan Tinggi Direktorat Ketenagaan, 2006

Fatonah, Sidiq, Konsep Penanganan Anak Bermasalah Menurut Alexander Sutherland Neill Dan Implikasinya Terhadap Pendidikan Islam, Jurnal Pendidikan Islam Vol 1 (1) Tahun 2014

Gay, L.R. dan Diehl, P.L, Research Methods for Business and. Management, MacMillan Publishing Company, New York, 1992

Ghichara, Jenny, Mengatasi Perilaku Buruk Anak, Jakarta: Kawan Pustaka, 2006

Hadi, M. Fahli Zatra, A. Muri Yusuf, Syahniar, Pemahaman Konselor Sekolah Tentang Tugas Perkembangan Siswa Dan Layanan Yang Diberikan, Jurnal Ilmiah Konseling Vol. 2 (1) tahun 2013

Hamid, Patilima, Metode Penelitian Kualitatif, Cetakan I; Bandung: Alfabeta, 2005

Harun,Cut Zahri, Manajemen Sumber Daya Pendidikan, Yogyakarta: Pena Persada, 2009

Heri, Gunawan, Pendidikan Karakter "Konsep dan Implementasi”, Bandung: Alfabetha, 2014

Inah, Ety Nur, Peran Komunikasi Dalam Interaksi Guru Dan Siswa, Jurnal Al-Ta'Dib Vol. 8 (2) 2015 
Kadarman dan Jusuf Udaya, Pengantar Ilmu Manajemen, Cet.2; Jakarta: Gramedia Pustaka Utama, 1992

Mahabbati, Aini, Pola Perilaku Bermasalah Dan Rancangan Intervensi Pada Anak Tunalaras Tipe Gangguan Perilaku (Conduct Disorder) Berdasarkan Functional Behavior Assessment, Jurnal Dinamika Pendidikan Vol. 01 (21) Tahun 2014

Maryatin, Peran Kepemimpinan Kepala Madrasah Dalam Meningkatkan Mutu Pendidikan Islam, Jurnal Kajian Pendidikan Islam Vol. 5 (2) Tahun 2013

Miftah, Thoha, Perilaku Organisasi “Konsep Dasar dan Aplikasinya, Cet. 8; Jakarta: Raja Grafindo, 1996

Mulyasa, Menjadi Kepala Sekolah Professional Dalam Konteks Menyukseskan MBSdan KBK, Bandung: PT Remaja Rosada Karya, 2003

Mustopadidjaja, Kebijakan Efektif dan Efisien, Jakarta: LAN RI Jakarta, 2009

Nurkumala Sari Br. Lubis, Peran Guru Dan Orang Tua Dalam Mengembangkan Minat Dan Bakat Anak Tunagrahita Di Slb Negeri Pembina Yogyakarta (Tesis Program Studi Pendidikan Sosiologi Jurusan Pendidikan Sejarah Fakultas Ilmu Sosial Universitas Negeri Yogyakarta, 2012)

Omboto, John Onyango, Gerald O. Ondiek, Odhiambo Odera, dan Mary Evelyn Ayugi, Factors Influencing Youth Crime And Juvenile Delinquency, International Journal of Research In Social Sciences, Vol. XX (28) Tahun 2015

P. Stephen, Robbins, Perilaku Organisasi, Penerjemah; Benyamin Molan, Jakarta: Indeks Kelompok Gramedia, 2006

Stan, Kossen, Aspek Manusiawi dalam Organisasi, Penerjemah; Bakri Siregar; Jakarta: Erlangga, 1993

Suharsimi, Arikunto, Prosedur Penelitian Suatu Pendekatan Praktik, Ed. Revisi, Cet. 14; Jakarta: Rineke Cipta, 2010

Suhid, Asmawati, Abdul Rahmah Md. Aroff, dan Norliana Kamal, "Factors Causing Student Absenteeism According To Peers" Jurnal Faculty of Education Studies University Putra Malaysia, Vol. 3 (24) Tahun 2012

Suwatno dan Priansa, Manajemen SDM dalam Organisasi Publik dan Bisnis, Bandung: Alfabeta, 2016

Umar, Tirtarahadja dan La Sulo, Pangantar Pendidikan, Ed. Revisi, Cet. I; Jakarta: Asdi Mahasatya, 2003

Wahyudi, Kepemimpinan Kepala Sekolah dalam Organisasi Pembelajar, Bandung: Alfabeta, 2012 